Original paper

\title{
Mineralogy and crystal chemistry of micas from the A-type El Portezuelo Granite and related pegmatites, Catamarca (NW Argentina)
}

\author{
Fernando COLOMBO ${ }^{1,2^{*}}$, Raúl LIRA', Michael J. DORAIS³ \\ ${ }^{1}$ CONICET-Museo de Mineralogía "Dr Stelzner" - Facultad de Ciencias Exactas, Físicas y Naturales, Universidad Nacional de Córdoba, \\ Vélez Sarsfield 299 (5000) Córdoba,Argentina; fosfatos@yahoo.com.ar \\ ${ }^{2}$ Current address: Cátedra de Geología General, Facultad de Ciencias Exactas, Físicas y Naturales, Universidad Nacional de Córdoba, \\ Vélez Sarsfield 1611 (X5016GCA) Córdoba, Argentina \\ ${ }^{3}$ Department of Geological Sciences, Brigham Young University, Provo, Utah 84602, USA \\ * Corresponding author
}

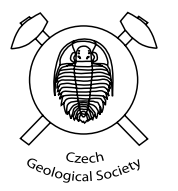

The A-type El Portezuelo Pluton (Catamarca, NW Argentina) is parental to an intragranitic suite of pegmatites of NYFtype affiliation (miarolitic class, miarolitic-rare earth element subclass, with features more similar to those reported for the gadolinite-fergusonite type). This study was performed on samples from the host granite and several zones of pegmatites, including crystals growing in miarolitic cavities and fine-grained overgrowths. Micas from the granite and massive pegmatites are rather homogeneous, but crystals coming from miarolitic cavities are usually sharply zoned with monocrystalline trioctahedral inner zones overgrown by polycrystalline dioctahedral rims. Dioctahedral micas are always paragenetically later.

Micas from the granite are intermediate members of the annite-siderophyllite series. From the outer pegmatite zones inwards the substitution ( $\mathrm{SiLi})\left({ }^{[4]} \mathrm{AlFe}\right)_{-1}$ in trioctahedral micas leads to compositions intermediate between siderophyllite and polylithionite, up to the composition $\mathrm{KLiFe}^{2+} \mathrm{Al}\left(\mathrm{AlSi}_{3}\right) \mathrm{O}_{10}(\mathrm{~F}, \mathrm{OH})_{2}$ (formerly called zinnwaldite). Dioctahedral micas also show a trend from near end-member muscovite to (Fe, $\mathrm{Mg}$, Li)-rich muscovite (phengite), according to the substitution $\left(R^{2+} \mathrm{Si}\right)\left({ }^{[4]} \mathrm{Al}{ }^{[6]} \mathrm{Al}\right)_{-1}$, where $R^{2+}=\mathrm{Fe}, \mathrm{Mg}, \mathrm{Mn}$; there is a compositional gap between dioctahedral and trioctahedral micas.

Zoned individual crystals have trioctahedral cores enriched in Fe, Mn and F; $\mathrm{Na}$, Li and Ti are usually also enriched in the cores, whereas $\mathrm{Mg}$ is usually depleted compared with the dioctahedral rims.

Micas in El Portezuelo are the most important F-bearing species (for their elevated F contents and their modal abundance) and they also have a major role in the distribution of $\mathrm{Li}$ and $\mathrm{Rb}$. The overall evolutionary trend is very similar to that found at the Pikes Peak Batholith (Colorado USA) and is characteristic of NYF-type granite-miarolitic pegmatite systems.

Keywords: NYF-type pegmatites, chemical evolution, siderophyllite, zinnwaldite, lithium, fluorine

Received: 12 October 2009; accepted 11 March 2010; handling editor: P. Nabelek

The online version of this article (doi: 10.3190/jgeosci.058) contains supplementary electronic material.

\section{Introduction}

As reported by Černý and Burt (1984), micas from anorogenic pegmatites have received much less attention than their counterparts from pegmatites of orogenic affiliation, and in spite of the long period of time that has elapsed since that statement the situation has not changed much. The two most detailed studies on micas from anorogenic pegmatites were performed by Foord et al. (1995) and Kile and Foord (1998), who examined micas from various occurrences in the Pikes Peak Batholith, central Colorado (USA), and confirmed that they are very good indicators of chemical evolution. However, similar studies encompassing host granite and related pegmatites are scarce in the literature.
A number of plutons with A-type affinities were emplaced during the Carboniferous in central and northwestern Argentina (Dahlquist et al. 2010). One of such bodies is the epizonal El Portezuelo Pluton, located in Belén Department (Catamarca Province), slightly east of the intersection of coordinates $67^{\circ} \mathrm{W}$ and $27^{\circ} \mathrm{S}$ (Figs $1 \mathrm{a}-\mathrm{b})$. This pluton is very similar to the Altohuasi Pluton, some $15 \mathrm{~km}$ due south, and together they are known as the Papachacra Granite. Only samples from the El Portezuelo stock were analyzed.

Since the early 1990's, well-formed crystals of microcline, quartz (amethyst and smoky quartz), albite, topaz, fluorite and other species have been collected from miaroles that occur scattered in the granite and within small pegmatitic segregations. Micas, while not truly 

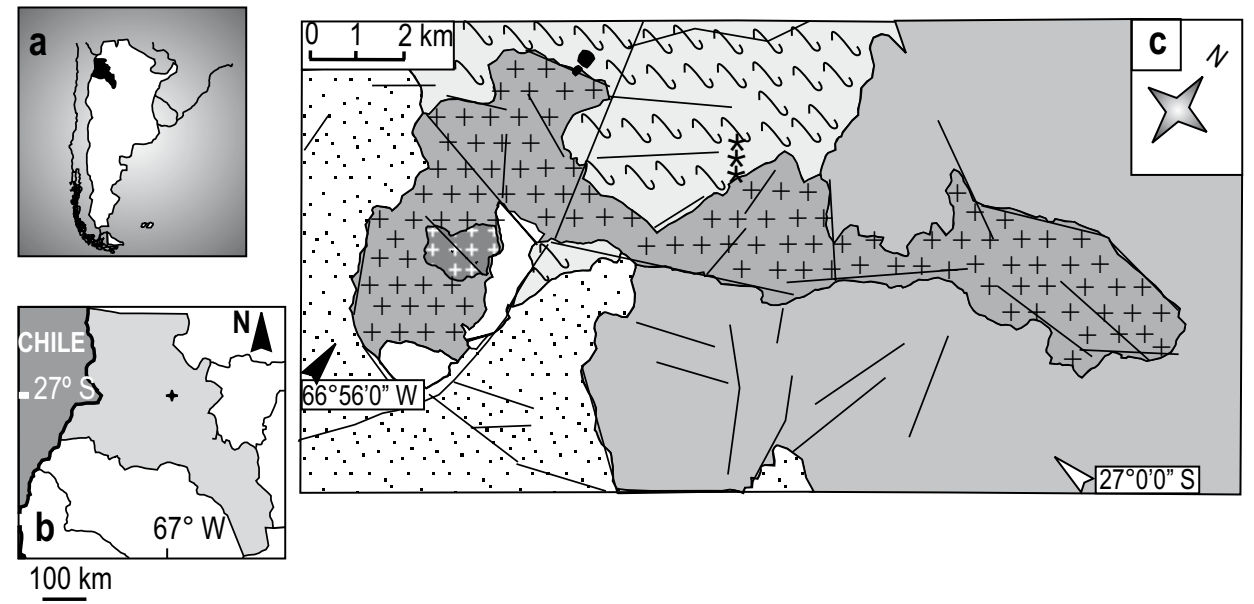

$100 \mathrm{~km}$

Fig. 1a - Location of Catamarca Province (black), in NW Argentina (white), in southern South America. b - Location of El Portezuelo Pluton (dark dot) in central Catamarca Province (light gray). c-Simplified geological map of the El Portezuelo Granite.

common, are often part of these assemblages, sometimes as strongly zoned crystals. Dark micas are also the main mafic accessory in the host granite and in pegmatites. Therefore, micas from El Portezuelo Pluton offer an interesting possibility of systematically examining the composition, extent and type of elemental substitutions and variations according to their paragenetic position, from the host granite to pegmatites and finally miaroles.

Unlike the studies by Foord et al. (1995) and Kile and Foord (1998), all the samples come from the same granitic body.

\section{Geological setting}

The El Portezuelo Pluton is elongated in a NE direction; its maximum dimensions are $\sim 16.5 \mathrm{~km}$ by $\sim 7.5 \mathrm{~km}$ (Fig. 1c). It intruded a greenschist-facies metapelitic sequence (Loma Corral Formation) and the Chango Real orthogneiss (Lazarte 1994). A suite of alkaline rocks (quartz monzonite, amphibole granite, syenite and comendite) is intruded in the El Portezuelo Granite, but it does not seem to be geochemically related to the biotite granite.

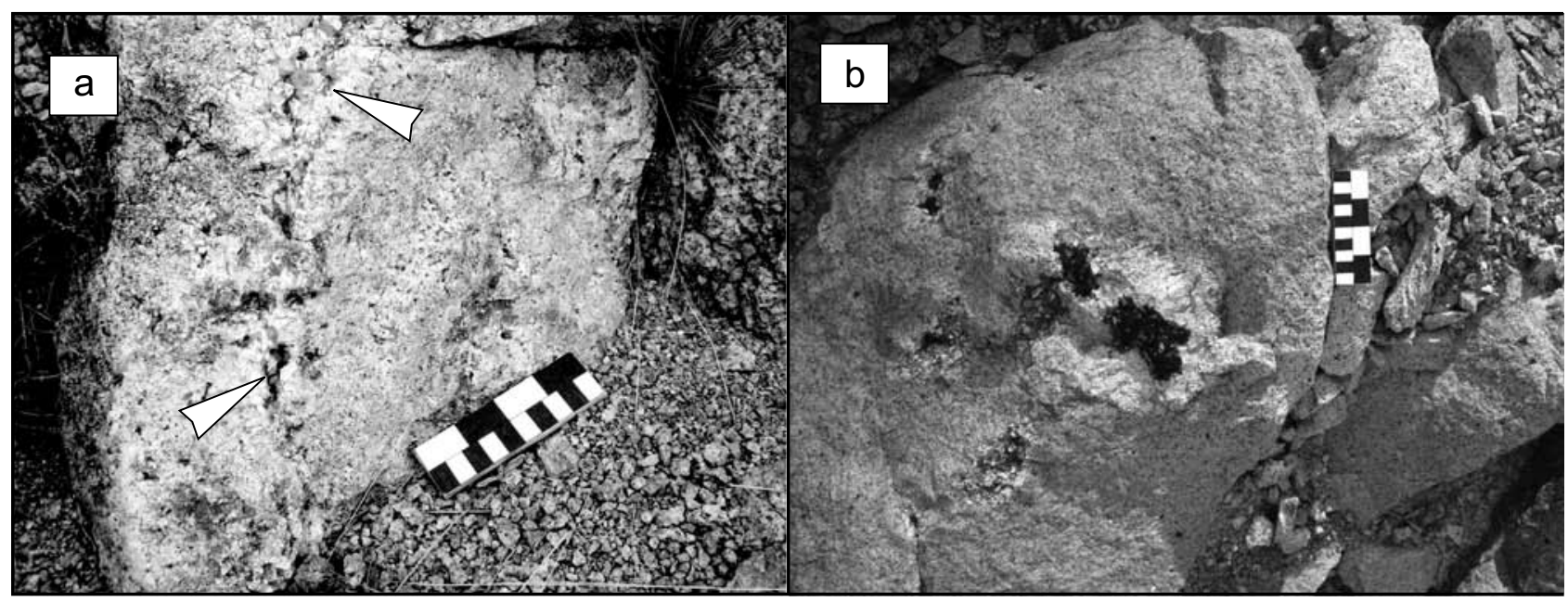

Fig. 2a - Aplite-pegmatite dike with an inner plane defined by flattened miarolitic cavities (marked by arrows). b - Leucocratic segregations in granite. Very often they have a central open cavity, but in this particular case the core is solid and composed of tourmaline (schorl to F-dominant schorl). Scale is shown in $\mathrm{cm}$ and inches. 
This granite [monzogranite to syenogranite in the QAP diagram of Le Maitre et al. (2002)] is composed mainly of quartz, K-feldspar (orthoclase and microcline) and plagioclase $\left(A n_{12}\right.$ to $\left.A n_{0}\right)$. Accessory species are dark mica (annite-siderophyllite series), fluorite, topaz, zircon, thorite, monazite-(Ce), xenotime-(Y), apatite, magnetite, ilmenite, rutile, uraninite, and columbite-(Fe). Secondary phases include cerianite-(Ce), chamosite, pyrochloresupergroup minerals and hematite.

Whole-rock analyses show that the granite is sub aluminous (Aluminum Saturation Index $~ 1.00$ ) and has a restricted compositional variation; it has high $\mathrm{SiO}_{2}\left(>75\right.$ wt. \%) and relatively low $\mathrm{Al}_{2} \mathrm{O}_{3}, \mathrm{Fe}_{2} \mathrm{O}_{3}{ }^{\mathrm{T}}$, $\mathrm{CaO}$ and $\mathrm{TiO}_{2}$. It is very poor in $\mathrm{P}_{2} \mathrm{O}_{5}(<0.03$ wt. \%) and $\mathrm{MgO}(<0.06$ wt. \%). Alkalies are not particularly enriched $\left[\left(\mathrm{Na}_{2} \mathrm{O}+\mathrm{K}_{2} \mathrm{O}\right) \sim 8.5 \%\right]$; $\mathrm{Rb}(545-730 \mathrm{ppm})$, $\mathrm{Nb}$ (69-109 ppm), Th (51-80 ppm) and U (9-31 ppm) are high whereas $\mathrm{Sr}(5-27 \mathrm{ppm}), \mathrm{Ba}(4-105 \mathrm{ppm})$, and $\mathrm{Eu}(0.37$ to less than $0.05 \mathrm{ppm})$ contents are low. The granite displays a marked negative Eu anomaly $\left(\mathrm{Eu} / \mathrm{Eu}^{*}\right.$ $=0.18-0.01)$. Analyses of two representative samples appear in Tab. 1.

The El Portezuelo Granite shows the chemical characteristics of low-phosphorus granites as defined by Taylor (1992) and it can be classified as A-type granite following the criteria outlined by Collins et al. (1982) and Whalen et al. (1987). Its age is not well constrained, but probably it was emplaced during the Late Devonian or Carboniferous (Rossello et al. 2000).

Miarolitic cavities, pegmatite pods and small aplitepegmatite dikes are abundant throughout the granite. Aplite-pegmatite dikes are relatively small, most being several tens of centimeters thick and can be followed for a few meters along strike. Some are banded, with portions of aplitic texture and other of pegmatitic grain size. Small miaroles, flattened parallel to the contacts, are common (Fig. 2a). Miaroles display textural and mineralogical zoning that closely matches that described by Černý (2000). Their size is very variable; the largest found measured $\sim 1.5 \mathrm{~m}$, but most are $\sim 20 \mathrm{~cm}$ or smaller. Miarolitic cavities usually have an outermost zone similar to the host granite but are depleted in biotite and with a slightly coarser grain size. This is followed by graphic intergrowths of quartz-microcline ( \pm albite) that coarsen inwards. The core is formed by quartz, microcline and albite crystals that often protrude into a clay-filled cavity. The central part may also be filled by quartz and tourmaline (Fig. 2b). In this contribution "pegmatitic micas" will refer to those occurring in the outer zones of the miarolitic pegmatites, whereas the term "miarolitic micas" means those crystals found growing in the open cavity.

Pegmatites belong to the NYF petrogenetic family (so called because they tend to concentrate Niobium, Yttrium and Fluorine) and are representatives of the miarolitic
Tab. 1 Representative analyses of granites from El Portezuelo Pluton

\begin{tabular}{|c|c|c|}
\hline wt. \% & 67 & 90 \\
\hline $\mathrm{SiO}_{2}$ & 76.13 & 77.32 \\
\hline $\mathrm{TiO}_{2}$ & 0.07 & 0.07 \\
\hline $\mathrm{Al}_{2} \mathrm{O}_{3}$ & 11.98 & 11.40 \\
\hline $\mathrm{Fe}_{2} \mathrm{O}_{3}{ }^{\mathrm{T}}$ & 1.26 & 0.77 \\
\hline $\mathrm{MnO}$ & 0.04 & 0.02 \\
\hline $\mathrm{MgO}$ & 0.06 & 0.04 \\
\hline $\mathrm{CaO}$ & 0.41 & 0.52 \\
\hline $\mathrm{Na}_{2} \mathrm{O}$ & 3.62 & 3.65 \\
\hline $\mathrm{K}_{2} \mathrm{O}$ & 4.92 & 4.23 \\
\hline $\mathrm{P}_{2} \mathrm{O}_{5}$ & 0.03 & 0.02 \\
\hline LOI & 0.95 & 0.91 \\
\hline Total & 99.45 & 98.93 \\
\hline \multicolumn{3}{|l|}{ ppm } \\
\hline $\mathrm{Ba}$ & 27 & 37 \\
\hline $\mathrm{Sr}$ & 10 & 16 \\
\hline $\mathrm{Y}$ & 79 & 60 \\
\hline $\mathrm{Zr}$ & 148 & 119 \\
\hline $\mathrm{Ga}$ & 28 & 24 \\
\hline $\mathrm{Rb}$ & 545 & 563 \\
\hline $\mathrm{Nb}$ & 99 & 82 \\
\hline Cs & 35.3 & 21.6 \\
\hline $\mathrm{La}$ & 47.7 & 37.8 \\
\hline $\mathrm{Ce}$ & 115.0 & 79.6 \\
\hline $\operatorname{Pr}$ & 11.70 & 8.30 \\
\hline $\mathrm{Nd}$ & 39.6 & 27.9 \\
\hline $\mathrm{Sm}$ & 8.4 & 5.9 \\
\hline $\mathrm{Eu}$ & 0.13 & 0.23 \\
\hline Gd & 7.0 & 5.8 \\
\hline $\mathrm{Tb}$ & 1.6 & 1.3 \\
\hline Dy & 10.6 & 8.3 \\
\hline Ho & 2.2 & 1.8 \\
\hline $\mathrm{Er}$ & 7.7 & 6.1 \\
\hline $\mathrm{Tm}$ & 1.52 & 1.16 \\
\hline $\mathrm{Yb}$ & 10.0 & 8.0 \\
\hline $\mathrm{Lu}$ & 1.47 & 1.20 \\
\hline $\mathrm{Hf}$ & 7.8 & 5.8 \\
\hline $\mathrm{Ta}$ & 15.8 & 12.5 \\
\hline Th & 63.4 & 56.2 \\
\hline U & 14.9 & 12.2 \\
\hline $\mathrm{Eu} / \mathrm{Eu}^{*}$ & 0.05 & 0.12 \\
\hline Lat S & $27^{\circ} 2^{\prime} 9.7^{\prime \prime}$ & $27^{\circ} 0 ’ 23.4^{\prime \prime}$ \\
\hline Long W & $66^{\circ} 54^{\prime} 57.4^{\prime \prime}$ & $66^{\circ} 54^{\prime} 3.3^{\prime \prime}$ \\
\hline
\end{tabular}

class, miarolitic-rare earth element subclass, with features more similar to those reported for the gadolinitefergusonite type, according to criteria suggested by Černý and Ercit (2005). 


\section{Samples and analytical methods}

Samples include crystals taken from granite, from coarsegrained segregations surrounding miarolitic cavities, and from cavity walls, implanted on both paragenetically early and late minerals. Primary dark mica from aplites is altered to chlorite or muscovite to variable degrees; a single sample of secondary muscovite after biotite has been included in the dataset (sample 62-N). A brief description of the samples can be found in Tab. 2. Trioctahedral micas occur in all of the rock types, whereas dioctahedral micas are restricted to late-stage associations in pockets or have a secondary origin.

Carbon-coated polished sections and mounts were analyzed using a CAMECA SX-50 electron microprobe at Brigham Young University, using $\mathrm{K}_{\alpha}$ lines. Standards included phlogopite (F), jadeite ( $\mathrm{Na}), \mathrm{MgO}(\mathrm{Mg})$, anorthite $(\mathrm{Al})$, orthoclase $(\mathrm{Si}, \mathrm{K})$, scapolite $(\mathrm{Cl})$, wollastonite $(\mathrm{Ca})$, titanite (Ti), spessartine (Mn) and fayalite (Fe). Raw data were processed using the Pouchou and Pichoir (1985) correction. Instrumental parameters were: $10 \mathrm{nA}, 15 \mathrm{kV}$, spot diameter $10 \mu \mathrm{m}$, counting time: $20 \mathrm{~s}$ on peak and $10 \mathrm{~s}$ at each side. Lithium contents were estimated from empirical correlation formulae (Tischendorf et al. 1997): $\mathrm{Li}_{2} \mathrm{O}=0.289 \times \mathrm{SiO}_{2}-9.658\left(\mathrm{R}^{2}=0.912\right)$ for trioctahedral micas and $\mathrm{Li}_{2} \mathrm{O}=0.3935 \times \mathrm{F}^{1.326}\left(\mathrm{R}^{2}=0.843\right)$ for dioctahedral micas. Fluorine analyses were conducted with a PC0 crystal with the background under the peak determined by the slope from a background point on the positive side, to avoid overlap with a $\mathrm{Fe} \mathrm{L}_{\alpha}$ peak. No direct $\mathrm{Li}$ analyses were obtained for comparison with calculated values, so an estimate of accuracy in this particular data set cannot be made.

Optical emission spectroscopy (OES-DCP) was used for the determination of $\mathrm{B}, \mathrm{Ga}$ and $\mathrm{Rb}$ of three samples at the University of New Orleans.

Rubidium is present at least in some crystals, as evidenced by a very small peak in EDS spectra at $13.36 \mathrm{keV}$ and confirmed by OES-DCP analyses (Tab. 3). However, the full dataset had already been acquired by that moment,

Tab. 2 Samples used in this study

\begin{tabular}{ll}
\hline From the host biotite granite \\
\hline 67 & Dark mica (accessory in granite). \\
86 & Dark mica (accessory in granite). \\
90 & Dark mica (accessory in granite). \\
& \\
\hline From pegmatites (exclusive or miarolitic cavities) \\
\hline $126-3$ & Dark mica from the outermost part of a pegmatitic pod with a miarolitic cavity in the center. \\
$126-2$ & Unzoned crystal, in the middle part of a pegmatitic pod with a miarolitic cavity in the center. \\
$120-\mathrm{A}$ & Interstitial dark mica partially replaced by schorl to F-dominant schorl in the core of a pegmatitic pod. This \\
& pegmatite has no miarolitic cavities (Fig. 3a).
\end{tabular}

From miarolitic cavities

68-1 Crystal with trioctahedral dark smoky core overgrown by a dioctahedral thin silvery rim.

68-2 Crystal with trioctahedral dark smoky core overgrown by a dioctahedral thin silvery rim.

J3 Complete crystal, no evident zoning.

J66 Zoned crystal.

ELJ-Ms center Silvery single crystal.

ELJ-Ms rim Olive green crystals growing on the rim of a single silvery crystal (see ELJ -Ms center).

FC 4-1 Crystal with faint zoning.

J21-3

FC 47

Hemispheres of silvery mica growing on a microcline crystal.

Unzoned silvery crystal.

Unzoned silvery crystal.

ELJ c

Crystal with trioctahedral dark smoky core overgrown by a dioctahedral thin silvery rim.

Crystal with trioctahedral dark smoky core overgrown by a dioctahedral thin silvery rim; this crystal comes from center of the same sample as 126-2 and 126-3.

$126-1$

$\mathrm{J} 35$

Single unzoned crystal.

FC 63

Single unzoned crystal.

FC 76

Strongly zoned crystal.

$62-\mathrm{N}$

Secondary muscovite after biotite.

Flor zonada Crystal from a cavity associated with florencite-(Ce).

Rumi Tucu A Crystal with trioctahedral dark smoky core overgrown by a dioctahedral thin silvery rim.

Rumi Tucu B Crystal with trioctahedral dark smoky core overgrown by a dioctahedral thin silvery rim.

$\mathrm{J} 70 \mathrm{~A}$

$\mathrm{J} 100$

Crystal whose core has been dissolved. J70B is a traverse made along a different line.

Unzoned crystal.

J71 Silvery crystal, unzoned, on the (001) face of a microcline crystal 
Tab. 3 DCP-OES analyses of micas from El Portezuelo

\begin{tabular}{lcccl}
\hline Sample & $\mathrm{Rb}_{2} \mathrm{O}(\%)$ & $\mathrm{Ga}(\mathrm{ppm})$ & $\mathrm{B}(\mathrm{ppm})$ & Origin \\
\hline Crystal-core & 1.41 & 613 & 22 & miarole \\
Crystal-rim & 0.70 & 746 & 44 & miarole \\
mica 230-A & 0.80 & 594 & 55 & $\begin{array}{l}\text { pegmatite } \\
\text { greisenized } \\
\text { pegmatite }\end{array}$ \\
mica 214 & 0.10 & 34 & 268 &
\end{tabular}

and $\mathrm{Rb}$ had not been included in the microprobe analytical routine. The zoning on a very fine scale precluded meaningful analyses of samples using bulk techniques, so analyses were normalized to 21 negative charges (allowing for $\mathrm{F}$ and $\mathrm{Cl}$ ), excluding the interlayer cations, to minimize the influence of non-analyzed constituents. All $\mathrm{Fe}$ was assumed to be $\mathrm{Fe}^{2+}$. This last assumption is not strictly valid (see Černý and Burt 1984) but we have no better way of constraining the actual $\mathrm{Fe}^{2+} / \mathrm{Fe}^{3+}$ ratio due to the zoning referred to above and lack of enough sample in other cases. Tetrahedral Al was calculated as (4-Si), and excess $\mathrm{Al}$ was assigned to the octahedral sites along with divalent cations (excluding $\mathrm{Ca}$ ) and $\mathrm{Ti}$.

Representative analyses appear in Tab. 4. The full dataset has been deposited as a supplementary file.

The $\beta$ refractive index was measured in homogeneous samples using Cargille liquids and white light; the estimated standard error is \pm 0.003 .

\section{Micas in El Portezuelo Granite and related pegmatites}

\subsection{Macroscopic aspect and paragenesis}

Dark mica is the most abundant accessory mineral in the granite, as subhedral to anhedral crystals reaching $4 \mathrm{~mm}$. It encloses inclusions of magnetite, zircon, thorite, monazite-(Ce), ilmenite, columbite-( $\mathrm{Fe})$ and an apatite-supergroup mineral. Some grains show partial to complete alteration to muscovite and chlorite.

Tab. 4 Representative analyses of micas from El Portezuelo

\begin{tabular}{|c|c|c|c|c|c|c|c|c|c|c|}
\hline \multirow[t]{2}{*}{ wt. $\%$} & \multicolumn{3}{|c|}{ Granite } & \multicolumn{3}{|c|}{ Pegmatite (exclusive of miaroles) } & \multicolumn{4}{|c|}{ Miarolitic cavity } \\
\hline & 67 & 86 & 90 & $126-3$ & $126-2$ & $120-\mathrm{a}$ & $\mathrm{J} 71$ & $126-1$ & J86-3 & 68-1 rim \\
\hline $\mathrm{SiO}_{2}$ & 35.01 & 36.08 & 35.99 & 38.85 & 39.54 & 40.68 & 45.81 & 41.28 & 45.00 & 46.84 \\
\hline $\mathrm{Al}_{2} \mathrm{O}_{3}$ & 19.56 & 13.95 & 18.39 & 19.83 & 21.80 & 22.21 & 26.95 & 22.14 & 21.04 & 27.39 \\
\hline $\mathrm{TiO}_{2}$ & 2.05 & 3.06 & 2.00 & 1.48 & 0.68 & 0.84 & 0.08 & 0.31 & 0.06 & 0.22 \\
\hline $\mathrm{FeO}$ & 27.52 & 30.20 & 27.34 & 21.22 & 18.62 & 17.56 & 9.62 & 17.51 & 14.37 & 8.03 \\
\hline $\mathrm{MnO}$ & 0.78 & 0.39 & 0.48 & 0.54 & 0.60 & 0.55 & 0.74 & 0.67 & 0.43 & 0.27 \\
\hline $\mathrm{MgO}$ & 0.98 & 2.45 & 1.13 & 0.94 & 0.47 & 0.77 & 0.03 & 0.50 & 0.10 & 0.66 \\
\hline $\mathrm{Li}_{2} \mathrm{O}$ calc & 0.46 & 0.77 & 0.74 & 1.57 & 1.77 & 2.10 & 1.75 & 2.27 & 3.35 & 1.53 \\
\hline $\mathrm{CaO}$ & n.d. & 0.03 & n.d. & n.d. & n.d. & 0.03 & n.d. & 0.01 & n.d. & n.d. \\
\hline $\mathrm{Na}_{2} \mathrm{O}$ & 0.21 & 0.03 & 0.15 & 0.22 & 0.17 & 0.24 & 0.09 & 0.22 & 0.15 & 0.03 \\
\hline $\mathrm{K}_{2} \mathrm{O}$ & 9.00 & 9.35 & 9.34 & 9.58 & 9.69 & 9.93 & 10.68 & 9.89 & 10.19 & 10.72 \\
\hline $\mathrm{F}$ & 3.40 & 1.16 & 3.09 & 5.15 & 5.18 & 5.69 & 3.08 & 5.68 & 6.65 & 2.79 \\
\hline $\mathrm{Cl}$ & 0.48 & 0.48 & 0.32 & 0.10 & 0.04 & 0.05 & n.d. & 0.03 & 0.03 & n.d. \\
\hline $\mathrm{H}_{2} \mathrm{O}$ calc & 2.25 & 3.17 & 2.42 & 1.70 & 1.73 & 1.61 & 3.01 & 1.63 & 1.32 & 3.18 \\
\hline Total & 100.16 & 100.51 & 100.00 & 98.99 & 98.10 & 99.85 & 100.54 & 99.73 & 99.88 & 100.48 \\
\hline \multicolumn{11}{|c|}{ apfu based on 210 eq. } \\
\hline $\mathrm{Si}$ & 2.635 & 2.818 & 2.717 & 2.795 & 2.820 & 2.820 & 3.074 & 2.857 & 3.008 & 3.116 \\
\hline $\mathrm{Al}$ & 1.735 & 1.284 & 1.636 & 1.681 & 1.833 & 1.815 & 2.131 & 1.806 & 1.658 & 2.148 \\
\hline $\mathrm{Ti}$ & 0.116 & 0.179 & 0.114 & 0.080 & 0.037 & 0.044 & 0.004 & 0.016 & 0.003 & 0.011 \\
\hline $\mathrm{Fe}$ & 1.732 & 1.972 & 1.726 & 1.276 & 1.111 & 1.018 & 0.540 & 1.013 & 0.803 & 0.447 \\
\hline $\mathrm{Mn}$ & 0.049 & 0.026 & 0.031 & 0.033 & 0.036 & 0.032 & 0.042 & 0.039 & 0.024 & 0.015 \\
\hline $\mathrm{Mg}$ & 0.110 & 0.285 & 0.127 & 0.101 & 0.050 & 0.079 & 0.003 & 0.052 & 0.010 & 0.065 \\
\hline $\mathrm{Li}$ & 0.139 & 0.242 & 0.225 & 0.454 & 0.507 & 0.585 & 0.471 & 0.632 & 0.899 & 0.409 \\
\hline $\mathrm{Ca}$ & 0.000 & 0.002 & 0.000 & 0.000 & 0.000 & 0.002 & 0.000 & 0.000 & 0.000 & 0.000 \\
\hline $\mathrm{Na}$ & 0.030 & 0.004 & 0.021 & 0.031 & 0.023 & 0.032 & 0.012 & 0.030 & 0.020 & 0.004 \\
\hline K & 0.864 & 0.932 & 0.900 & 0.879 & 0.882 & 0.878 & 0.914 & 0.873 & 0.869 & 0.909 \\
\hline $\mathrm{F}$ & 0.810 & 0.286 & 0.737 & 1.171 & 1.169 & 1.247 & 0.653 & 1.244 & 1.405 & 0.586 \\
\hline $\mathrm{Cl}$ & 0.062 & 0.063 & 0.040 & 0.012 & 0.005 & 0.006 & 0.000 & 0.004 & 0.004 & 0.000 \\
\hline
\end{tabular}


In aplite-pegmatites and miarolitic pegmatites dark mica, occurring as crystals up to $2 \mathrm{~mm}$ long, is typically interstitial between quartz, $\mathrm{K}$-feldspar (microcline $>>$ orthoclase in massive pegmatites and aplites, only microcline in miaroles), and plagioclase crystals. Dark micas in the sampled aplitic dikes have been completely replaced by chamosite or muscovite. In the inner zones of the miarolitic pegmatites (exclusive of the open cavity) dark mica can be partially replaced by tourmaline (schorl to F-dominant schorl, Fig. 3a).

Although micas are never abundant, several generations can be found inside the miarolitic cavities. Paragenetically they range from early, intergrown with, and protruding from, quartz (usually dark smoky), albite (white to pale blue) and microcline crystals, to late, growing on corroded crystals and filling fractures. Pseudohexagonal tabular crystals up to over $10 \mathrm{~cm}$ have been found (Fig. 3b), but most commonly they reach up to $c .2 \mathrm{~cm}$ along the (001) face. Prismatic crystals (Fig. $3 c)$ are rather rare. Many samples consist of a dark smoky or blackish trioctahedral core surrounded by epitactic polycrystalline overgrowths of pale dioctahedral mica (Figs 3d-f). The contact between the two phases has been altered and removed in some cases, leaving an empty space. Under the microscope a very fine-scale color zoning in the core (and less well-defined in the rim) is readily apparent. Some of the more common accessory minerals growing in miarolitic cavities (either nucleated on the surface of the crystals or included in them) are fluorite, topaz, rutile, $\mathrm{Nb}-\mathrm{Ta}$ oxides (pyrochlore supergroup, columbite group, tapiolite-(Fe) and unidentified species containing $\mathrm{Y} \pm \mathrm{REE}, \mathrm{U})$, hematite, ilmenite, monazite$(\mathrm{Y})$, zircon, thorite, xenotime-( $\mathrm{Y})$ and black tourmaline (schorl-foitite solid solution). Microcline, the most abundant rock-forming mineral in miaroles, is off-white to yellowish or pale pink; green K-feldspar (amazonite) has not been found.

The last generation of hydrothermal mica occurs as small colorless crystals or pale greenish spheroidal aggregates, covering microcline and quartz crystals and

Tab. 4 (Continued). Representative analyses of micas from El Portezuelo

\begin{tabular}{|c|c|c|c|c|c|c|c|c|c|c|}
\hline \multirow[t]{2}{*}{ wt. $\%$} & \multicolumn{10}{|c|}{ Miarolitic cavity } \\
\hline & $68-1$ core & J66 rim-1 & J66 core-2 & $\mathrm{J} 100$ & $\mathrm{~J} 100$ & $\mathrm{~J} 70 \mathrm{~B}$ & Rumi Tucu A & Rumi Tucu B & FC 76 & FC 76 \\
\hline $\mathrm{SiO}_{2}$ & 40.90 & 43.95 & 45.20 & 47.22 & 46.16 & 46.11 & 46.83 & 46.85 & 44.96 & 39.13 \\
\hline $\mathrm{Al}_{2} \mathrm{O}_{3}$ & 21.67 & 27.06 & 21.86 & 20.66 & 20.96 & 34.73 & 30.05 & 26.35 & 29.17 & 21.09 \\
\hline $\mathrm{TiO}_{2}$ & 0.62 & 0.17 & 0.11 & 0.09 & 0.09 & n.d. & 0.04 & 0.09 & n.d. & 0.56 \\
\hline $\mathrm{FeO}$ & 17.41 & 11.75 & 13.82 & 11.56 & 11.82 & 2.99 & 4.95 & 8.06 & 8.20 & 20.34 \\
\hline $\mathrm{MnO}$ & 0.54 & 0.51 & 0.48 & 0.47 & 0.48 & 0.05 & 0.28 & 0.26 & 0.36 & 0.91 \\
\hline $\mathrm{MgO}$ & 1.11 & 0.09 & 0.06 & 0.02 & 0.04 & n.d. & 0.97 & 0.13 & 0.14 & 0.54 \\
\hline $\mathrm{Li}_{2} \mathrm{O}$ calc & 2.16 & 1.66 & 3.40 & 3.99 & 3.68 & 0.32 & 1.36 & 1.96 & 1.39 & 1.65 \\
\hline $\mathrm{CaO}$ & n.d. & n.d. & n.d. & n.d. & n.d. & n.d. & n.d. & n.d. & n.d. & n.d. \\
\hline $\mathrm{Na}_{2} \mathrm{O}$ & 0.22 & 0.14 & 0.27 & 0.24 & 0.25 & 0.24 & 0.08 & 0.07 & 0.21 & 0.16 \\
\hline $\mathrm{K}_{2} \mathrm{O}$ & 9.90 & 10.59 & 10.04 & 10.27 & 10.14 & 11.02 & 10.77 & 11.00 & 10.80 & 9.63 \\
\hline $\mathrm{F}$ & 5.93 & 2.96 & 7.56 & 8.30 & 7.84 & 0.86 & 2.54 & 3.36 & 2.59 & 4.83 \\
\hline $\mathrm{Cl}$ & 0.05 & n.d. & 0.03 & n.d. & n.d. & n.d. & n.d. & 0.02 & n.d. & 0.06 \\
\hline $\mathrm{H}_{2} \mathrm{O}$ calc & 1.50 & 3.00 & 0.98 & 0.70 & 0.84 & 4.11 & 3.34 & 2.88 & 3.22 & 1.86 \\
\hline Total & 99.49 & 100.64 & 100.60 & 100.03 & 99.00 & 100.07 & 100.13 & 99.60 & 99.94 & 98.71 \\
\hline \multicolumn{11}{|c|}{ apfu based on $21 \mathrm{O}$ eq. } \\
\hline $\mathrm{Si}$ & 2.835 & 2.989 & 2.965 & 3.054 & 3.036 & 3.061 & 3.085 & 3.136 & 3.031 & 2.815 \\
\hline Al & 1.770 & 2.169 & 1.690 & 1.575 & 1.625 & 2.718 & 2.332 & 2.079 & 2.318 & 1.788 \\
\hline $\mathrm{Ti}$ & 0.032 & 0.008 & 0.005 & 0.004 & 0.004 & 0.000 & 0.002 & 0.005 & 0.000 & 0.030 \\
\hline $\mathrm{Fe}$ & 1.009 & 0.668 & 0.758 & 0.625 & 0.650 & 0.166 & 0.273 & 0.451 & 0.462 & 1.223 \\
\hline $\mathrm{Mn}$ & 0.032 & 0.030 & 0.027 & 0.026 & 0.027 & 0.003 & 0.016 & 0.014 & 0.020 & 0.056 \\
\hline $\mathrm{Mg}$ & 0.115 & 0.010 & 0.005 & 0.002 & 0.004 & 0.000 & 0.095 & 0.013 & 0.014 & 0.058 \\
\hline $\mathrm{Li}$ & 0.602 & 0.453 & 0.898 & 1.038 & 0.974 & 0.086 & 0.359 & 0.529 & 0.376 & 0.477 \\
\hline $\mathrm{Ca}$ & 0.000 & 0.000 & 0.000 & 0.000 & 0.000 & 0.000 & 0.000 & 0.000 & 0.000 & 0.000 \\
\hline $\mathrm{Na}$ & 0.029 & 0.018 & 0.034 & 0.029 & 0.032 & 0.031 & 0.010 & 0.009 & 0.028 & 0.022 \\
\hline $\mathrm{K}$ & 0.875 & 0.919 & 0.840 & 0.848 & 0.850 & 0.933 & 0.904 & 0.939 & 0.929 & 0.884 \\
\hline $\mathrm{F}$ & 1.300 & 0.636 & 1.568 & 1.697 & 1.630 & 0.180 & 0.530 & 0.712 & 0.552 & 1.099 \\
\hline $\mathrm{Cl}$ & 0.006 & 0.000 & 0.003 & 0.000 & 0.000 & 0.000 & 0.000 & 0.002 & 0.000 & 0.007 \\
\hline
\end{tabular}




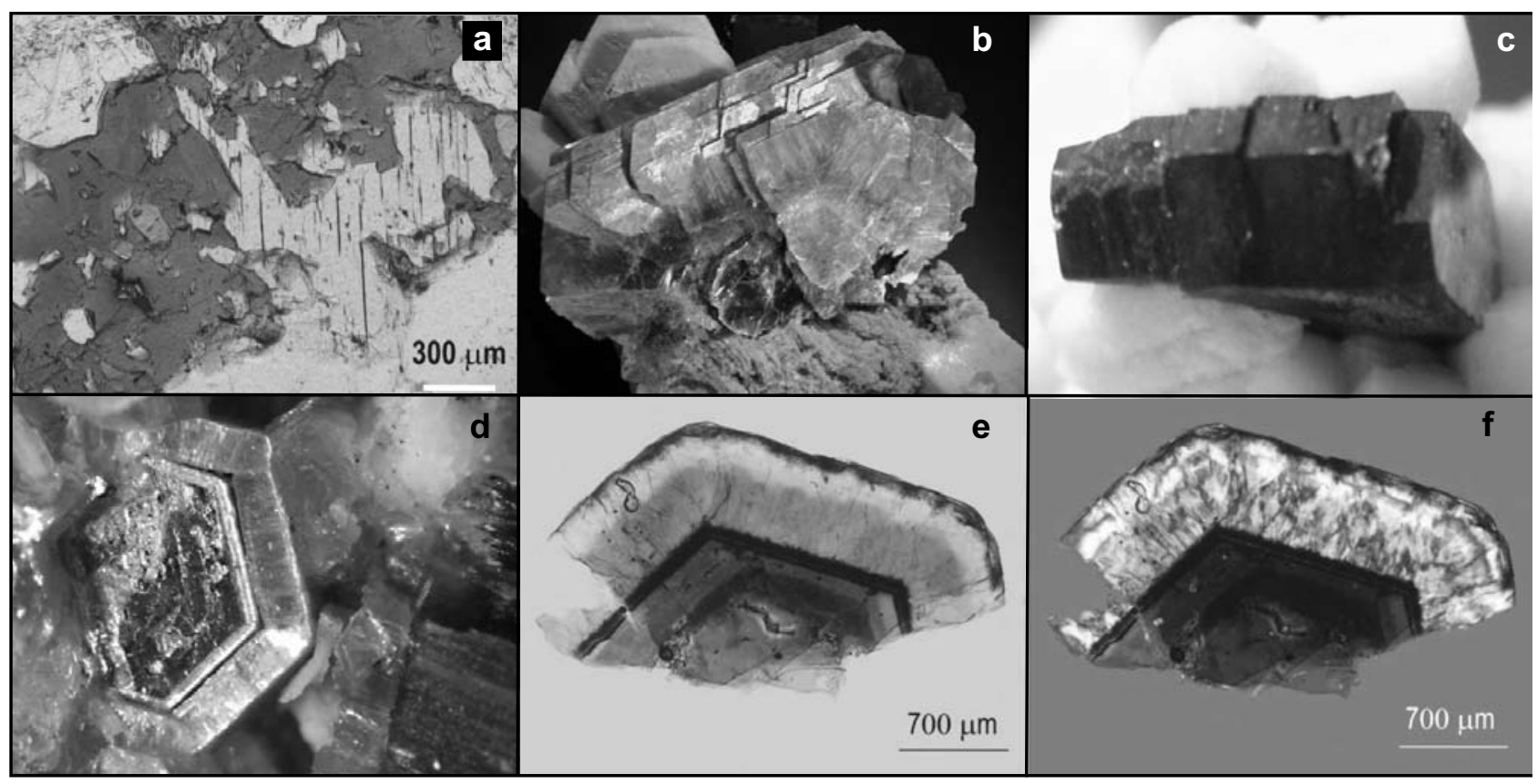

Fig. 3a - Photomicrograph (parallel polars) of mica partially replaced by F-dominant schorl, in the inner zone of a leucocratic segregation (see Fig. 2b). Colorless minerals are microcline and quartz. b - Tabular crystal $(10 \mathrm{~cm}$ across $)$ of mica showing a strong color zoning, growing on microcline and albite. $\mathbf{c}$ - Prismatic mica crystal $(7 \mathrm{~mm}$ long). $\mathbf{d}$ - Crystal showing a dark brown trioctahedral core with epitactic overgrowth of a silvery dioctahedral rim. The dark line along the contact is a physical discontinuity. e - Photomicrograph of a crystal similar to that of Fig. $3 \mathrm{~d}$ (parallel polars), showing color zoning. f - The same crystal under partially crossed polars. The core (trioctahedral) is a single crystal but the rim (dioctahedral) is polycrystalline.

penetrating along cracks. Other minerals typically present at this paragenetic stage are bertrandite and florencite(Ce). Mica can also form waxy or scaly masses of pale greenish yellow color filling small cavities, associated with brookite, anatase and zircon.

\subsection{Chemical composition}

\subsubsection{Intercrystalline variation}

Considering the whole dataset, the elements showing the most pronounced changes are $\mathrm{Si}, \mathrm{Al}, \mathrm{Li}, \mathrm{Fe}$ and $\mathrm{K}$. Fluorine is notably enriched in some samples, reaching over $8 \mathrm{wt} \%$. Contents of Ti, $\mathrm{Mg}, \mathrm{Na}$ and $\mathrm{Cl}$ are low (except for $\mathrm{Ti}$ in micas from the granite), sometimes below detection limit, and $\mathrm{Ca}$ is undetectable in most samples. Even the least evolved compositions show a high $\mathrm{Fe} /(\mathrm{Fe}$ $+\mathrm{Mg}$ ) ratio (0.85), as is typical of mafic accessories in A-type granites.

In covariation diagrams (Fig. 4), micas from the granite usually define a separate field compared to those from pegmatites and miaroles. There is partial overlap of most elemental pairs between the compositions of micas from pegmatites and miaroles, although micas from pegmatites span a more limited compositional range.
Among the trioctahedral micas, Fe displays an inverse correlation with $\mathrm{Si}$ and ${ }^{[6]} \mathrm{Al}$, whereas there is a positive correlation with $\mathrm{Ti}$ and $\mathrm{Mg}$. Manganese shows no meaningful correlation with $\mathrm{Fe}$. The positive correlation with $\mathrm{Cl}$ and negative with $\mathrm{F}$ ( $\mathrm{Fe}-\mathrm{F}$ avoidance principle) have already been described, among others, by Muñoz (1984) and Icenhower and London (1997) and explained on theoretical grounds by Mason (1992). In an evolved magmatic system like the one described here, it is possible that this trend is reinforced during the normal fractionation; $\mathrm{Fe}$ is gradually consumed whereas $\mathrm{F}$ accumulates in the residual melt, leading to an inverse correlation. The geochemical trend from granite to miaroles is towards a depletion in $\mathrm{Fe}, \mathrm{Mg}, \mathrm{Ti}$ and $\mathrm{Cl}$, along with an increase in $\mathrm{Si},{ }^{[6]} \mathrm{Al}$ and $\mathrm{F}$. Variations are often smooth, but $\mathrm{Ti}$ and $\mathrm{Mg}$ decrease abruptly in pegmatitic micas.

Those correlations suggest that one of the possible substitution mechanisms is $\mathrm{Li}+\mathrm{Si} \leftrightarrow \mathrm{R}^{2+}+{ }^{[4]} \mathrm{Al}$, where $\mathrm{R}^{2+}$ is dominantly $\mathrm{Fe}$ (but also including $\mathrm{Mn}$ and $\mathrm{Mg}$ ). The $\mathrm{R}^{2}$ value for this substitution is very high $\left(\mathrm{R}^{2}=\right.$ 0.9687), indicating that it explains most of the chemical variation (Fig. 5a). This substitution has also been previously found, inter alia, by Hawthorne and Černý (1982), Černý and Burt (1984), Henderson et al. (1989), Stone et al. (1997) and Lowell and Ahl (2000). 

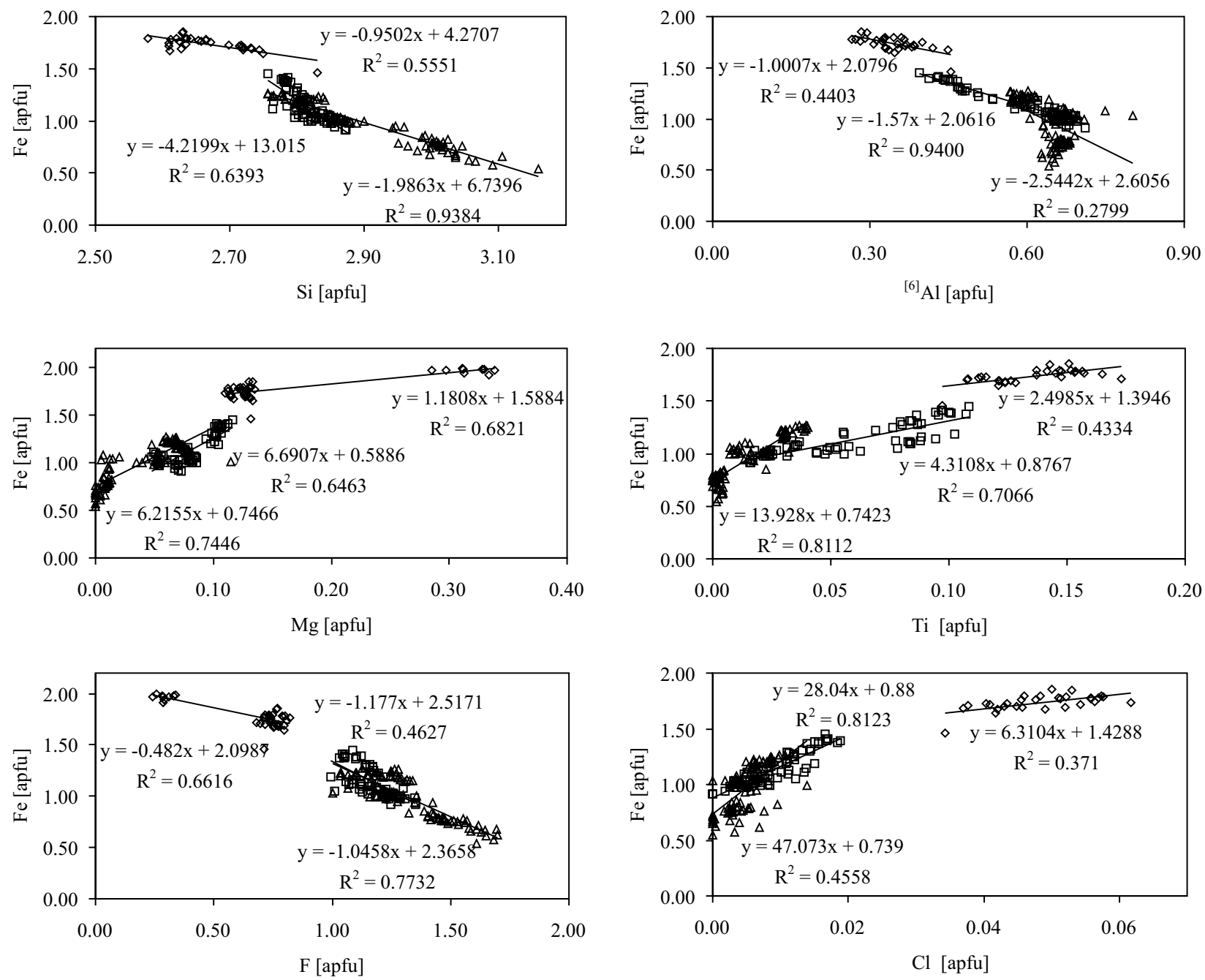

Fig. 4 Covariation diagrams of elements in trioctahedral micas from the granite and pegmatites (both enclosed in other minerals and growing as free-standing crystals in miarolitic cavities). Micas from pegmatites and miarolitic cavities have been treated separately but they could probably be considered a single population. In the case of Si vs. Fe diagram, the cluster of analyses from granite 86 plots off the main trend and has not been taken into account for the regression analysis. Symbols: squares: granite; diamonds: pegmatites; triangles: miarolitic cavities.

Titanium reaches almost 3 wt. \% $\left(\mathrm{as}_{\mathrm{TiO}}\right)$; however, a full evaluation of substitutions involving Ti requires complete chemical analyses, as some of the possible exchanges involve deprotonation and octahedral vacancies (as reviewed in Waters and Charnley 2002).

As regards the interlayer cations, the content of $\mathrm{Na}$ increases slightly in the sequence granite $(0.022(1)$ apfu, $\mathrm{n}=39) \rightarrow$ pegmatite $(0.0233(8)$ apfu, $\mathrm{n}=58) \rightarrow$ miaroles $(0.027(1)$ apfu, $n=91)$. The number of vacancies increases in the same sequence, from 0.090(3) apfu (granite) to 0.094(1) apfu (pegmatites) to 0.102(2) apfu (miaroles). This probably reflects an increasing role for cations that were not analyzed, mainly $\mathrm{Rb}$ but possibly also $\mathrm{H}_{3} \mathrm{O}^{+}$.

Chemical variations in dioctahedral micas are more limited, and the only correlations are between $\mathrm{Fe}$ and
$\mathrm{Mn}$ (positive, weak) and between ${ }^{[6]} \mathrm{Al}$ and $\mathrm{Fe}$ (negative, strong). The compositions can be described by the phengitic substitution ${ }^{[4]} \mathrm{Al}+{ }^{[6]} \mathrm{Al} \leftrightarrow \mathrm{Si}+\mathrm{R}^{2+}\left(\mathrm{R}^{2+}=\mathrm{Fe}, \mathrm{Mn}\right.$, $\mathrm{Mg}$ ) (Fig. 5b). The incorporation of Li seems to occur via the substitutions $2{ }^{[6]} \mathrm{Li}+{ }^{[4]} \mathrm{Si} \leftrightarrow{ }^{[4]} \mathrm{Al}+{ }^{[6]} \mathrm{Al}+\square$ and 3 ${ }^{[6]} \mathrm{Li} \leftrightarrow{ }^{[6]} \mathrm{Al}+2 \square$, as evidenced by the relationship (not shown) between Li apfu and octahedral sites occupied in excess of 2.00 apfu (see Hawthorne and Černý 1982). Analyses scattered outside the theoretical limits are probably due to the uncertainties associated with the $\mathrm{Li}$ content, which was calculated and not measured.

Compositional trends are clearly visible using the diagram proposed by Tischendorf et al. (2004), where the abscissa is $\mathrm{Mg}-\mathrm{Li}(m g l i)$ and the ordinate is $\mathrm{Fe}+\mathrm{Mn}$ $+\mathrm{Ti}-{ }^{[6]} \mathrm{Al}$ (feal), expressed in atoms per formula unit, apfu (Fig. 6a). 

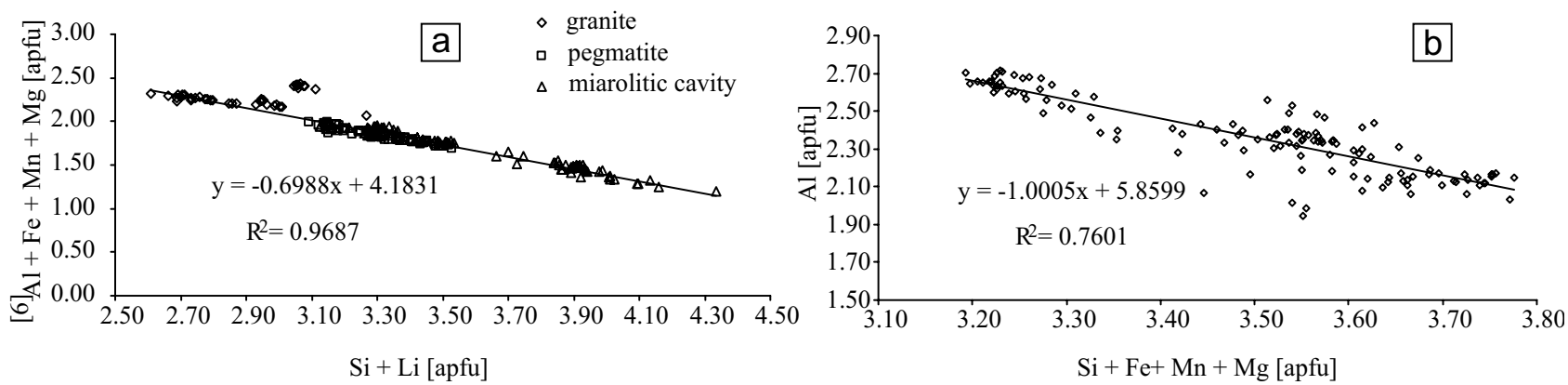

Fig. 5 Substitutions in trioctahedral micas (a) and dioctahedral micas (b). All plotted dioctahedral micas come from miarolitic cavities. Biotite from a granite sample (86) plots off the main trend and has not been included in the regression analysis.
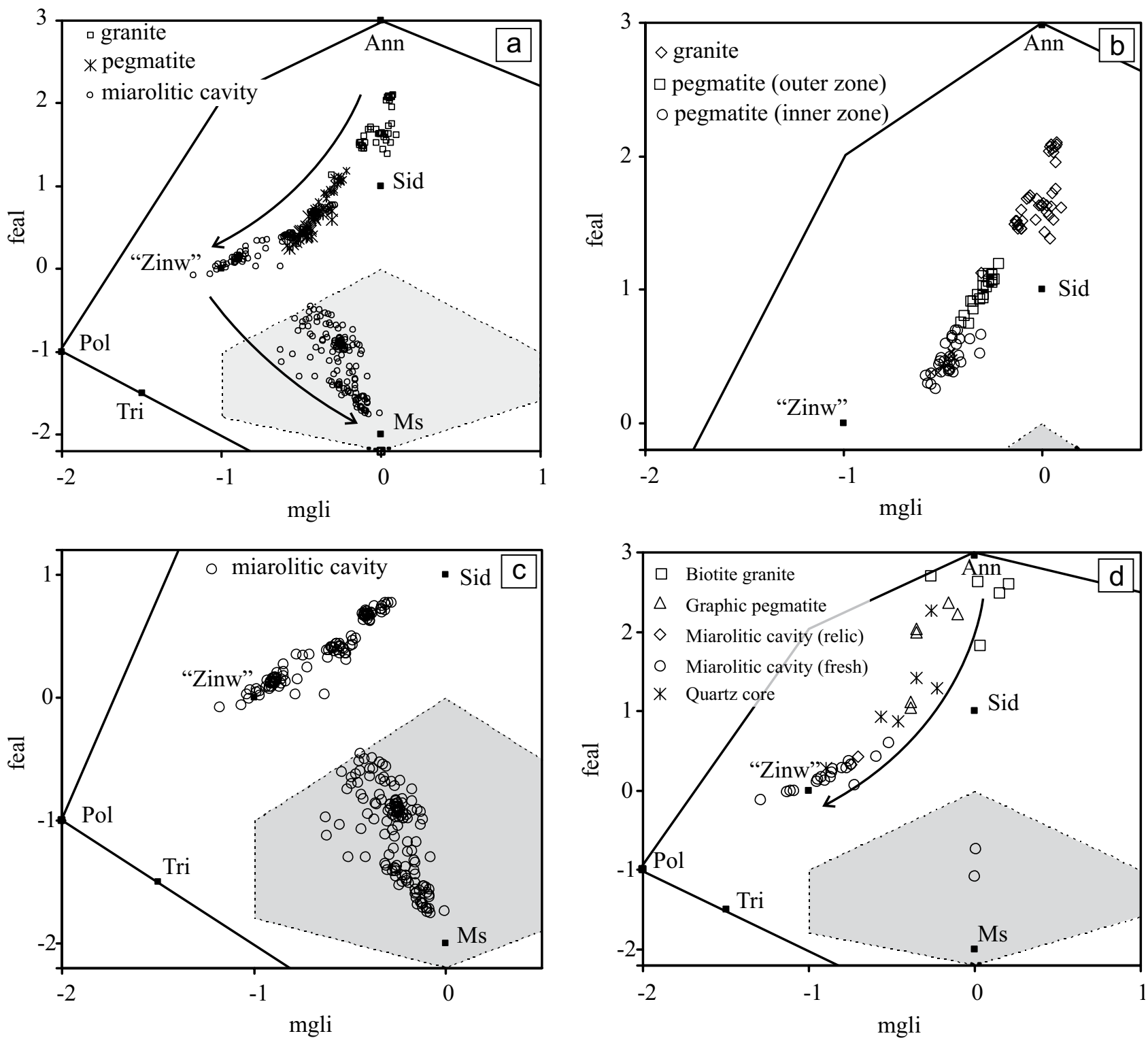

Fig. 6a - Compositions of micas from El Portezuelo plotted in the diagram of Tischendorf et al. (2004), with arrows showing the evolutionary trend. Black squares mark the positions of ideal annite (Ann), siderophyllite (Sid), "zinnwaldite", not an IMA-recognized species ("Zinw"), polylithionite (Po), trilithionite (Tri) and muscovite (Ms). The shaded field corresponds to dioctahedral micas. b - Detail of (a), showing the composition of micas from the granite and pegmatites. $\mathbf{c}$-Compositions of micas from miarolitic cavities; there is some overlap with those from pegmatites but not with dark micas from the granite. The compositional gap between trioctahedral and dioctahedral micas is clearly seen. $\mathbf{d}$ - Compositions of micas from the Pikes Peak Batholith (taken from Kile and Foord 1998), showing the same evolutionary trend as those from El Portezuelo. 
Micas from the granite are intermediate between annite and siderophyllite. The vertical trend is due to variations in ${ }^{[6]} \mathrm{Al}$ vs. $(\mathrm{Fe}+\mathrm{Mn}+\mathrm{Ti})$. Micas from pegmatites have a positive sloping trend, the result of a combination of lower feal (higher ${ }^{[6]} \mathrm{Al}$ and less $\mathrm{Fe}$ and $\mathrm{Ti}$ ) and more negative $m g l i$ (due to an increase in $\mathrm{Li}$ and depletion in $\mathrm{Mg}$ ). Micas sampled closer to the centre of the pegmatite body have the highest $\mathrm{Li}$ and $\mathrm{Al}$ contents (Fig. 6b). Crystals growing on miaroles extend this trend towards even more negative $m g l i$ values and lower feal, until they reach the composition $\mathrm{KLiFe}^{2+} \mathrm{Al}\left(\mathrm{AlSi}_{3}\right)$ $\mathrm{O}_{10}(\mathrm{~F}, \mathrm{OH})_{2}$ formerly known as zinnwaldite (Rieder et al. 1998) (Fig. 6c).

There are some compositions that plot towards the dioctahedral field, but there is no compositional continuum, coincident with the known gap between trioctahedral and dioctahedral micas.

Micas in the dioctahedral field define a continuous trend from almost pure end-member muscovite towards compositions with higher feal (due to increasing $\mathrm{R}^{2+}$ ) and more negative $m g l i$ (increasing Li) (Fig. 6c).

The composition of secondary muscovite (as an alteration product of biotite, sample 62-N) overlaps with the array of dioctahedral micas in Fig. 6c.

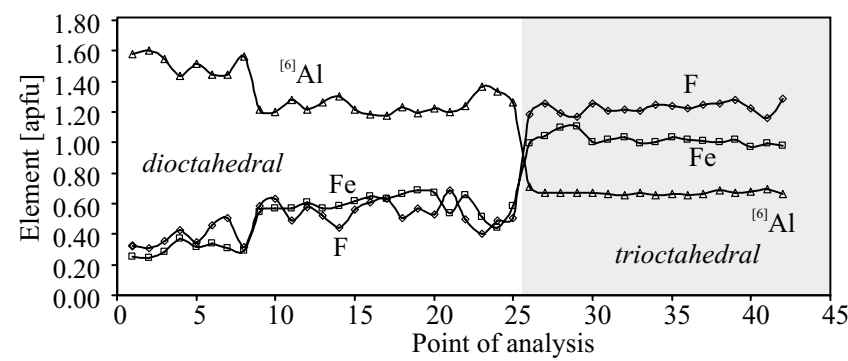

\subsubsection{Intracrystalline variation}

Crystals from the host granite and from pegmatites (border and graphic zones) are relatively homogeneous. Variations seen in Fig. 5 and 6 arise mainly because analyses made on different samples are plotted together.

Most crystals from miaroles are zoned on a very fine scale, in some cases finer than can be resolved by a microprobe. In many cases crystals are comprised of two species, with a trioctahedral core (single crystal) and a polycrystalline dioctahedral rim (the inverse has not been observed), separated by a sharp transition and sometimes by a physical discontinuity a few tenths of $\mathrm{mm}$ wide (Fig. 3d). The origin of this last feature seems to be related to preferential dissolution along the contact between the monocrystalline trioctahedral core and the polycrystalline dioctahedral overgrowth.

When examined in detail, some elements are systematically depleted or enriched in the trioctahedral or dioctahedral crystals, but the behavior of some others varies according to the sample being analyzed (Fig. 7). Among the first group of elements, $\mathrm{Fe}, \mathrm{Mn}$ and $\mathrm{F}$ are always enriched in trioctahedral micas. The $\mathrm{Na}, \mathrm{Li}$ and $\mathrm{Ti}$ contents are somewhat variable but most often they are also enriched

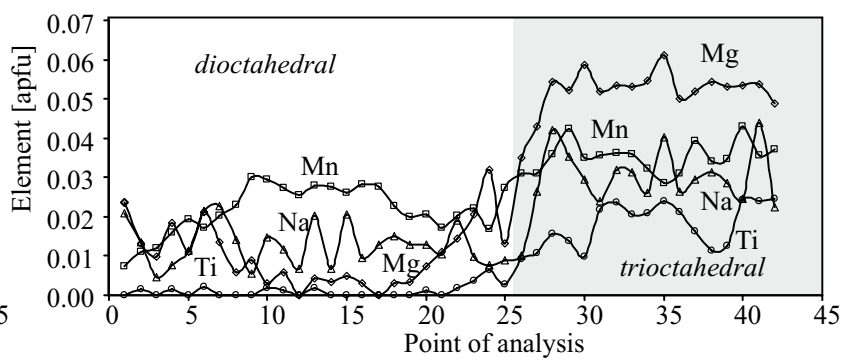

Fig. 7 Profiles from core (right) to rim (left) of sample 126-1, coming from a miarole.

Tab. 5 Refractive index $(\beta)$ and $\mathrm{TiO}_{2}$ and $\mathrm{FeO}^{\mathrm{T}}$ contents

\begin{tabular}{lcccr}
\hline Sample & $\beta$ & $\mathrm{TiO}_{2}$ (wt. \%) & $\mathrm{FeO}^{\mathrm{T}}$ (wt. \%) & $\mathrm{n}$ \\
\hline trioctahedral & & & & \\
\hline 86 & 1.657 & 2.86 & 30.38 & 9 \\
67 & 1.652 & 2.57 & 27.86 & 20 \\
90 & 1.650 & 2.03 & 26.58 & 10 \\
120-A & 1.610 & 0.99 & 17.68 & 30 \\
68-2 core 1 & 1.591 & 0.14 & 17.41 & 1 \\
126-3 & 1.624 & 1.59 & 21.73 & 20 \\
126-2 & 1.609 & 0.57 & 17.66 & 8 \\
J86-3 & 1.580 & 0.10 & 14.67 & 22 \\
\hline dioctahedral & & & & \\
\hline J70 & 1.592 & n.d. & 3.18 & 9 \\
J71 & 1.587 & 0.03 & 8.60 & 5 \\
$68-2$ rim 1 & 1.571 & 0.05 & 2.01 & 1 \\
Flor zonada & 1.586 & 0.05 & 3.88 & 5 \\
\hline
\end{tabular}

$n=$ the number of averaged samples in trioctahedral crystals, whereas $\mathrm{Mg}$ is usually depleted. ${ }^{[6]} \mathrm{Al}$ is always depleted in trioctahedral micas, whereas $\mathrm{Cl}$ does not show a definite behavior. It is possible that enrichment or depletion trends, especially in some minor elements, are largely influenced by other co-crystallizing phases like oxides, tourmaline and feldspars.

A considerable compositional range can be found in a single crystal (Fig. 8). This is especially marked in dioctahedral micas.

\subsection{Optical properties}

Only 12 samples ( 8 of which are trioctahedral) were reasonably homogeneous so as to allow an examination of the relationship between chemical composition and the $\beta$ refractive index of micas (Tab. 5).

Correlation between chemical composition and $\beta$ was not observed for dioctahedral micas, whereas triocta- 


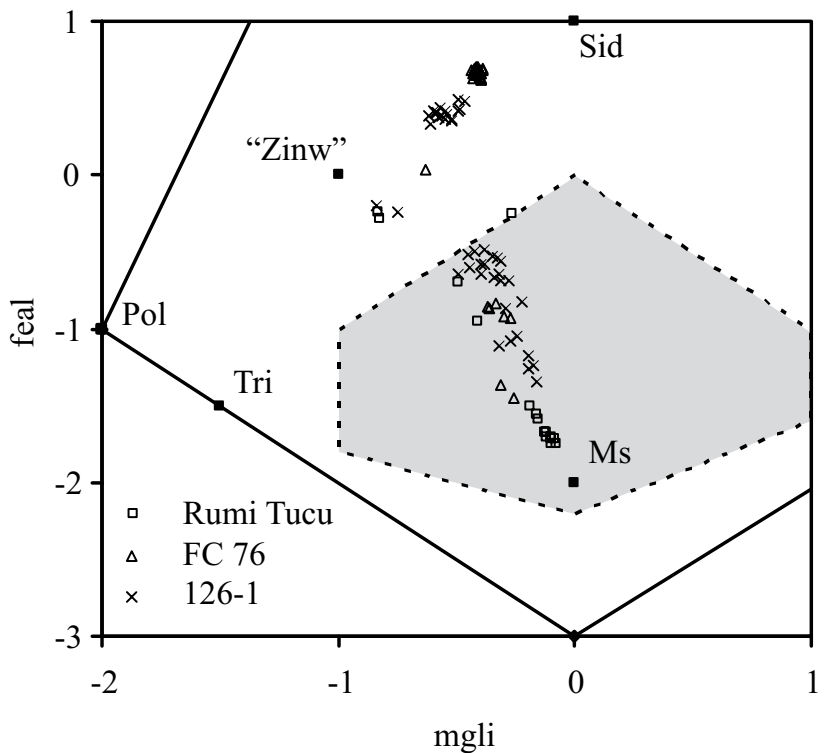

Fig. 8 Compositions of three composite crystals (trioctahedral cores with dioctahedral overgrowths) plotted in the diagram of Tischendorf et al. (2004). Mineral abbreviations as in Fig. 6.

hedral micas show a strong correlation between $\beta, \mathrm{FeO}$ and $\mathrm{TiO}_{2}$ (Fig. 9) Other cations do not show meaningful correlations. These relationships have previously been observed by Hall (1941), Heinrich (1946), Rieder et al. (1971) and Kile and Foord (1998), among others. These authors found that increased values of $\beta$ were correlated with higher $\mathrm{Ti}$ and $\mathrm{Fe}$ (especially $\mathrm{Fe}^{3+}$ ). In the case of the samples from El Portezuelo, both $\mathrm{Ti}$ and Fe (oxidation state undetermined) behave sympathetically, and thus it is not possible to isolate their effects. However, correlation of chemical composition with $\beta$ is still a rapid method of estimating the $\mathrm{Fe}$ and $\mathrm{Ti}$ content of micas for a qualitative assessment of their degree of evolution.

\section{The evolution of the granite-pegmatite system: inferences from micas}

Several lines of evidence suggest that El Portezuelo was emplaced at a shallow depth. It intrudes very low grade metasedimentary rocks (slates), with a thermal aureole that extends at the most a few meters from the contact. The presence of abundant miaroles places an approximate upper limit to the pressure, as this texture is best developed in bodies crystallized at pressures lower than c. $250 \mathrm{MPa}$ (Candela and Blevin 1995). Normative percentages of the host granite coincide approximately with the Qtz-Ab-Or proportions of haplogranitic melt at $100 \mathrm{MPa}$, according to the diagram compiled by London (1992).

Whole-rock contents of major $(\mathrm{Fe}, \mathrm{Ti}, \mathrm{Ca})$ and trace elements ( $\mathrm{Sr}, \mathrm{Ba}, \mathrm{Cs})$ parallel the evolutionary trend
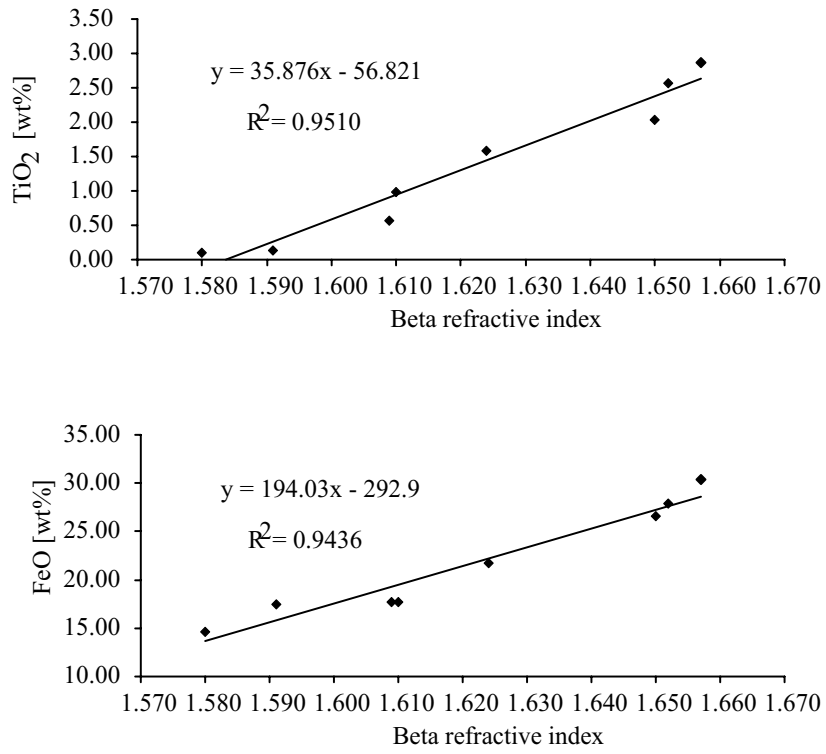

Fig. 9 Covariation of the $\beta$ refractive index, $\mathrm{FeO}$ and $\mathrm{TiO}_{2}$.

shown by biotites from the granite, and indicate that there is some cryptic zoning in the pluton (at least in the western lobe), with the most evolved compositions at the southern end.

With rare exceptions, pegmatites related to the El Portezuelo Pluton are intragranitic. There is no apparent relationship between size and position (vertical vs. subhorizontal) of the aplite-pegmatite dikes and the size of the miaroles they may contain.

According to London's model (London 2008), crystallization in pegmatites occurs in undercooled magmas through a thin volatile-rich boundary layer whose composition is different from that of the coexisting bulk magma. However, the content of miarolitic cavities probably crystallized entirely from the boundary layer itself, as it is the very last liquid in the latest stage of consolidation (London 2008). An alternative model invokes the coexistence of immiscible melts (associated or not to a low-density aqueous-rich fluid) from where minerals in the pegmatite miaroles would precipitate (Thomas et al. 2009). The compositional continuum of micas from the host granite to pegmatites and finally miaroles reflects a closed-system behavior, at least with regard to major and minor elements (but see below).

Zoning in micas has sometimes been attributed to changes in confining pressure (e.g. Clarke and Bogutyn 2003). In the case of miaroles from El Portezuelo Pluton, the very fine scale of the zoning would imply many cycles of pressure build-up and release. Evidences of sudden decompression, like broken and rehealed crystals, have indeed been found in some pegmatites. However, we do not consider very likely that the amount of volatiles 
that could possibly exsolve from a small $(\sim 20 \mathrm{~cm}$ or less in diameter, as most miarolitic pegmatites are) mass of cooling magma could be enough to cyclically raise pressure to values exceeding those of the confining rock. In this case we consider that it is more probable that chemical variations are related to changes in diffusion rates of excluded components (Kile and Foord 1998, London 2008). Dioctahedral micas start to crystallize when the residual liquid is exhausted of the elements which enter preferentially in trioctahedral micas (most notably $\mathrm{Fe}, \mathrm{Li}$ and F). Alternatively, this transition could be caused by a single event of pressure release, which could cause major changes in the chemistry of the fluids and favor epitactic nucleation at many sites, leading to polycrystalline rims. It is worth mentioning that $\mathrm{O}$ isotopes measured in miarolitic quartz (our unpublished data) suggest that the isotopic signature is not purely magmatic. The moment of the exchange with a different fluid and how it affected the chemistry and stability of the growing crystals is still a matter of research.

In this granite-pegmatite system $F$ is notably enriched, a hallmark of A-type granites and associated NYF pegmatites. The fact that rutile and fluorite, but not titanite, are minor accessories in the biotite granite is an evidence of the high $\mathrm{F}$ content, as the reaction $\mathrm{CaTiSiO}_{5}+\mathrm{F}_{2} \mathrm{O}_{-1}$ $=\mathrm{CaF}_{2}+\mathrm{TiO}_{2}+\mathrm{SiO}_{2}$ is displaced to the right when $\mathrm{F}$ exceeds 1 wt. \% (Price et al. 1999). An estimation of the $\mathrm{F}$ content of the magma using the equation of London (1997) was only possible for the least evolved mica from the granite (sample 86), because the others were outside the calibration limits. For a $100 \mathrm{Mg} /(\mathrm{Mg}+\mathrm{Mn}+\mathrm{Fe})$ ratio of 13.72, and a F content of 1.19 wt. \% in biotite (both values are average of 9 analyses), the calculated $\mathrm{F}$ content of the magma is 3.93 wt. \% F. Even though F content of biotite may not be primary, but rather reflect reequilibration during outgassing or with hydrothermal fluids (Icenhower and London 1997; Price et al. 1999), at least qualitatively it can be said that $\mathrm{F}$ in magma exceeded $\sim 1 \mathrm{wt} . \%$. This element is incompatible in most igneous minerals and partitions preferentially in melt over vapor (Webster 1990). Its content increased with differentiation, reaching very high values in miaroles, where some mica analyses give $\mathrm{F}$ values in excess of $8 \mathrm{wt}$. \% (up to 8.30 wt. $\%, c .85 \%$ of the monovalent anions). Other minerals with possibility of F-for-OH substitution, like topaz, tourmaline and microlite, are also very F-rich (Colombo 2007; Colombo et al. 2009).

From a geochemical perspective, micas in El Portezuelo are the most important F-bearing species (for their elevated $\mathrm{F}$ contents and their modal abundance). They also have a large influence on the distribution of $\mathrm{Li}$ and $\mathrm{Rb}$. In phosphorus-rich systems, Li-bearing minerals in granites and pegmatites are usually members of the montebrasite-ambligonite and triphylite-lithiophilite solid solution series, along with spodumene, petalite, elbaite and micas of the lepidolite series (London and Burt 1982). In contrast, in P-depleted systems such as those typical of NYF pegmatites, $\mathrm{Li}$ is hosted mainly in Fe-rich micas (Hawthorne and Černý 1982). In the El Portezuelo pegmatites the only other possible Li sink is tourmaline. However, microprobe analyses indicate that they belong to the schorl-foitite solid solution, and very little Li is likely to be present. This confirms that micas constitute the major Li-bearing minerals in this granitepegmatite system.

Micas also play an important role as one of the major $\mathrm{Rb}$-bearing minerals in these pegmatites, as evidenced by the value of 1.41 wt. $\% \mathrm{Rb}_{2} \mathrm{O}$ measured in the core of a mica crystal. In granitic systems $\mathrm{K}$-feldspar is also a very important $\mathrm{Rb}$ carrier, although experimental studies (Icenhower and London 1995, 1996) predict that in granitic melts $\mathrm{Li}$ and $\mathrm{Rb}$ will be preferentially partitioned into mica rather than alkali feldspar. Microprobe analyses of K-feldspars $(n=103)$ from granite, pegmatites, miarolitic cavities and fissure linings confirm this, as they show a maximum content of 0.39 wt. $\% \mathrm{Rb}_{2} \mathrm{O}$, far below the value measured in mica. In spite of the very different $\mathrm{Rb}$ contents, in this case $\mathrm{K}$-feldspar is modally much more abundant than mica, and so it plays a non-negligible role in the $\mathrm{Rb}$ distribution.

\section{Comparison with similar occurrences}

To the best of our knowledge, the only comparable studies on micas from anorogenic granites and pegmatites have been performed by Foord et al. (1995) and by Kile and Foord (1998), who studied micas from plutons belonging to the Pikes Peak Batholith (Colorado, USA). When plotted in the diagram of Tischendorf et al. (2004), micas from El Portezuelo and Pikes Peak show striking similarities (Fig. 6d). Both display trends from annitesiderophyllite towards polylithionite reaching the composition formerly attributed to "zinnwaldite". Compared with micas from the host granites, those from graphic pegmatites and quartz cores from Pikes Peak are slightly offset towards more negative values along the $m g l i$ axis (because of their higher Li content), whereas micas from miarolitic cavities plot in the same field. The sequence is exactly the same as outlined above for micas from El Portezuelo. Dioctahedral micas are barely represented in the dataset of Kile and Foord (1998); it remains to be confirmed if this is a real difference in the mineralogy of micas from Pikes Peak compared with those of El Portezuelo or if it is a sampling artifact.

A remarkable feature of the micas from El Portezuelo is that the entire trend is displayed by micas from a single granite body, unlike those described by Kile 
and Foord (1998) who studied samples from several plutons.

Acknowledgements We are grateful to George Morgan and an anonymous reviewer for their constructive criticism, and to Peter Nabelek for his remarkable patience during the editorial process. William Simmons and Alexander Falster (University of New Orleans) are acknowledged for their help with EDS and DCP-OES analyses of micas and for the microprobe (WDS) analyses of feldspars, topaz and microlite. This study is part of FC's Ph.D. dissertation funded by CONICET. Fabián Juárez kindly assisted during the field work, and Eduardo L. Jawerbaum loaned samples for study.

Electronic supplementary material. The complete table of mica electron microprobe analyses is available online at the Journal web site (http://dx.doi.org/10.3190/ jgeosci.058).

\section{References}

Candela PA, Blevin PL (1995) Do some miarolitic granites preserve evidence of magmatic volatile phase permeability? Econ Geol 90: 2310-2316

Clarke DB, Bogutyn PA (2003) Oscillatory epitacticgrowth zoning in biotite and muscovite from the Lake Lewis leucogranite, South Mountain Batholith, Nova Scotia, Canada. Canad Mineral 41: 1027-1047

Collins WJ, Beams SD, White AJR, Chappell BW (1982) Nature and origin of A-type granites with particular reference to Southeastern Australia. Contrib Mineral Petrol 80: 189-200

Colombo F (2007) Geology, mineralogy and genesis of Atype granitoids and their associated pegmatites in the El Portezuelo Composite Pluton (Papachacra Granite, Catamarca Province). Unpublished Ph.D. thesis, Universidad Nacional de Córdoba, pp 1-479 (in Spanish)

Colombo F, Lira R, Pannunzio Miner EV (2009) Mineralogical characterization of topaz from miarolitic pegmatites and W-bearing greisen in the A-type El Portezuelo Granite, Papachacra (Catamarca Province). Rev Asoc Geol Arg 64: 194-200

ČERNÝ P (2000) Constitution, petrology, affiliations and categories of miarolitic pegmatites. In: Pеzzotta F (ed) Mineralogy and Petrology of Shallow-depth Pegmatites. Mem Soc Ital Sci Nat e del Museo Civico di Storia Naturale di Milano 30: 5-12

ČERnÝ P, BuRT DM (1984) Paragenesis, crystallochemical characteristics, and geochemical evolution of micas in granitic pegmatites. In: BAILEY SW (ed) Micas. Mineralogical Society of America Reviews in Mineralogy 13: pp 257-297
ČERNÝ P, ERCIT TS (2005) The classification of granitic pegmatites revisited. Canad Mineral 43: 2005-2026

Dahlquist Ja, Alasino PH, Eby GN, Galindo C, Casquet C (2010) Fault controlled Carboniferous A-type magmatism in the proto-Andean foreland (Sierras Pampeanas, Argentina): geochemical constraints and petrogenesis. Lithos 115: 65-81

Foord EE, ČERnÝ P, JaCKSON LL, Sherman DM, Eby RK (1995) Mineralogical and geochemical evolution of micas from miarolitic pegmatites of the anorogenic Pikes Peak Batholith, Colorado. Mineral Petrol 55: 1-26

Hall AJ (1941) The relation between chemical composition and refractive index in the biotites. Amer Miner 26: $34-41$

Hawthorne FC, Č́erný P (1982) The micas. In: ČERnÝ P (ed) Granitic Pegmatites in Science and Industry. Mineralogical Association of Canada, Short Course Handbook 8: pp 63-98

HeInRICH EW (1946) Studies in the mica group; the biotitephlogopite series. Amer J Sci 244: 836-848

Henderson CMB, Martin JS, Mason RA (1989) Compositional relations in Li-micas from S.W. England and France: and ion- and electron-microprobe study. Mineral Mag 53: 427-449

ICENHOWER JP, LONDON D (1995) An experimental study of element partitioning between biotite, muscovite and coexisting peraluminous granitic melt at $200 \mathrm{MPa}\left(\mathrm{H}_{2} \mathrm{O}\right)$. Amer Miner 80: 1229-1251

ICENHOWER JP, LONDON D (1996) Experimental partitioning of $\mathrm{Rb}, \mathrm{Cs}, \mathrm{Sr}$, and $\mathrm{Ba}$ between alkali feldspar and per aluminous melt. Amer Miner 81: 719-734

ICENHOWER JP, LONDON D (1997) Partitioning of fluorine and chlorine between biotite and granitic melt: experimental calibration at $200 \mathrm{MPa} \mathrm{H}_{2} \mathrm{O}$. Contrib Mineral Petrol 127: $17-29$

Kile DE, Foord EE (1998) Micas from the Pikes Peak Batholith and its cogenetic granitic pegmatites, Colorado; optical properties, composition, and correlation with pegmatite evolution. Canad Mineral 36: 463-482

LAZARTE JE (1994) Geology and geochemistry of the Papachacra Granite (Carboniferous?), Pampean Ranges, Catamar ca. Rev Asoc Geol Arg 49: 337-352 (in Spanish)

Le Maitre RW, Streckeisen A, Zanettin B, Le Bas MJ, Bonin B, Bateman P (eds) (2002) Igneous Rocks. A Classification and Glossary of Terms. Cambridge University Press, Cambridge, pp 1-236

LoNDON D (1992) The application of experimental petrology to the genesis and crystallization of granitic pegmatites. Canad Mineral 30: 499-540

LONDON D (1997) Estimating abundances of volatile and other mobile components in evolved silicic melts through mineral-melt equilibria. J Petrol 38: 1691-1706

London D (2008) Pegmatites. Canad Mineral Special Publication 10: pp 1-347 
LONDON D, BuRT DM (1982) Lithium minerals in pegmatites. In: Černý P (ed) Granitic Pegmatites in Science and Industry. Mineralogical Association of Canada, Short Course Handbook 8: pp 99-133

Lowell GR, Ahl M (2000) Chemistry of dark zinnwaldite from Bom Futuro tin mine, Rondônia, Brazil. Mineral Mag 64: 699-709

MAson RA (1992) Models of order and iron-fluorine avoidance in biotite. Canad Mineral 30: 343-354

MuÑOZ JL (1984) F-OH and Cl-OH exchange in micas with applications to hydrothermal ore deposits. In: BAILEY SW (ed) Micas. Mineralogical Society of America Reviews in Mineralogy 13: pp 469-493

Pouchou J-L, Pichoir F (1985) "PAP" ( $\varphi \rho Z)$ procedure for improved quantitative microanalysis. In: Microbeam Analysis - 1985, San Francisco Press, San Francisco, pp 104-106

Price JD, Hogan JP, Gilbert MC, London D, Morgan VI GB (1999) Experimental study of titanite-fluorite equilibria in the A-type Mount Scott Granite: implications for assessing $\mathrm{F}$ contents of felsic magma. Geology 27: 951-954

Rieder M, Píchová A, Fassová M, Fediuková E, Černý P (1971) Chemical composition and physical properties of lithium-iron micas from the Krušné Hory Mts (Erzgebirge). Part B: cell parameters and optical data. Mineral Mag 38: 190-196

Rieder M, Cavazzini G, D'yakonov YS, Frank-KamenetskiI VA, Gottardi G, Guggenheim S, Koval PV, Müller G, Neiva AMR, Radoslovich EW, Robert J-L, SAssi FP, Takeda H, Weiss Z, Wones DR (1998) Nomenclature of the micas. Canad Mineral 36: 905-912

Rossello EA, López de Lucchi MG, Ostera H (2000) The Papachacra Formation (Belén, Catamarca): K/Ar ages and tectonic and metallogenetic significance. IX Cong Geol Chileno, Proceedings I. Puerto Varas, pp 360-364 (in Spanish)

Stone M, Klomínský J, Rajpoot GS (1997) Composition of trioctahedral micas in the Karlovy Vary Pluton, Czech Republic and a comparison with those in the Cornubian Batholith, SW England. Mineral Mag 61: 791-807

TAYLOR RP (1992) Petrological and geochemical characteristics of the Pleasant Ridge zinnwaldite-topaz granite, southern New Brunswick, and comparison with other topaz-bearing felsic rocks. Canad Mineral 30: 895-921

Thomas R, Davidson P, Rhede D, Leh M (2009) The miarolitic pegmatites from the Königshain: a contribution to understanding the genesis of pegmatites. Contrib Mineral Petrol 157: 505-523

Tischendorf G, Gottesmann B, Förster H-J, Trumbull RB (1997) On Li-bearing micas: estimating Li from electron microprobe analysis and an improved diagram for graphical representation. Mineral Mag 61: 809-834

Tischendorf G, Rieder M, Förster H.-J, Gottesmann B, Guidotti CV (2004) A new graphical presentation and subdivision of potassium micas. Mineral Mag 68: 649-667

Waters DJ, Charnley NR (2002) Local equilibrium in polymetamorphic gneiss and the titanium substitution in biotite. Amer Miner 87: 383-396

Webster JD (1990) Partitioning of $\mathrm{F}$ between $\mathrm{H}_{2} \mathrm{O}$ and $\mathrm{CO}_{2}$ fluids and topaz rhyolite melt: implications for mineralizing magmatic-hydrothermal fluids in F-rich granitic systems. Contrib Mineral Petrol 104:424-438

Whalen JB, Currie KL, Chappell BW (1987) A-type granites: geochemical characteristics, discrimination and petrogenesis. Contrib Mineral Petrol 95: 407-419 